\begin{tabular}{l|l} 
DE \\
$\bar{G}$
\end{tabular} $\begin{gathered}\text { DE GRUYTER } \\
\text { OPEN }\end{gathered}$

\title{
THE ANALYSIS OF AGRICULTURAL PRODUCTS EXPORT COMPETITIVENESS OF THE REPUBLIC OF SERBIA BASED ON THE RCA INDEX *
}

\section{Milica Cvetković}

\author{
University of Niš, Faculty of Economics, Republic of Serbia \\ $\triangle$ milica.cvetkovic85@yahoo.com
}

\section{Marija Petrović-Ranđelović}

University of Niš, Faculty of Economics, Republic of Serbia

$\bowtie$ marija.petrović@eknfak.ni.ac.rs

\section{UDC}

633/635:33

9.564(497.1

1)

Review

paper

\begin{abstract}
Agriculture of the Republic of Serbia is a significant economic branch, due to the specifics of production, tradition and because of the enormous potential that it holds for improving competitive performance and development of the national economy. For this reason, in all strategic documents agriculture is recognised as a vital branch for the development of the national economy, which can be achieved by an increase in productivity and greater foreign exchange, especially with the neighbouring countries. Bearing in mind that agricultural food products represent a very important part of foreign trade of the Republic of Serbia with the countries of the Western Balkans, the goal of the research is to point out the comparative advantages of the Republic of Serbia in the exchange of agricultural and food products with the countries in the region, by applying the Balassa index. The realisation of the principal objective of the research was carried out using the methods of comparative advantage, historical method, trends method, methods of analysis and synthesis. The results of research show that the Republic of Serbia has distinct comparative advantages in relation to the countries in the Western Balkans, with the exception of the Republic of Croatia. The key contribution of this paper lies in providing a clearer insight into the comparative advantages of the Republic of Serbia in foreign trade with the countries in the region, as well as pointing out the priority directions of activities of competent authorities in order to intensify.
\end{abstract}

\footnotetext{
* This paper is part of the project named "Improvement of the competitiveness of the public and private sector by networking the competencies in the process of European integrations of Serbia” financed by Ministry of Education, Science and Technological Development of Republic of Serbia.
} 
the agricultural export, especially high quality and products at a higher level of processing.

Received:

Keywords: comparative advantage, agriculture, RCA indicator, the

09.05.2017.

Republic of Serbia, the Western Balkan countries.

Accepted:

20.08.2017.

JEL classification: F10, O130, Q10, Q170

\section{Introduction}

The competitiveness presents "a set of institutions, policies and factors that determine the level of productivity of a country" (World Economic Forum, 2008, p. 3). It expresses the capability of the economy that in the medium term at the current level of development generates sustainable economic growth. Very often this term identifies with the concept of competition, even there are essential terminology differences between these two concepts. The competition is a market phenomenon and it refers to the market matching that is established between market participants.

At the micro level, generally agreed methodology is the methodology for measuring competitiveness, and it refers to the analysis of certain indicators related to specific market segments in which the particular company is active and on the market position of the analysed company. At the macro level, the country's competitiveness is defined as the ability of countries to achieve economic growth faster than other countries and to increase the well-being so that the economic structure changes and adapts better to the movement of international trade. The definition of competitiveness at the national level often departs from previous research that sublime theoretical knowledge of competition, which is not significantly changed even today. According to some authors, the most important aspects of the competitiveness are the possibility of selling in the global market (export), the ability to attract investments and the ability to create and increase in disposable income (Nešić, 2008, p. 49).

The export competitiveness of the national economy, in practice, is usually seen from the aspect of comparative advantages. Although these two concepts are theoretically close, they are not completely identical. The concept of comparative advantage says that the country will express a comparative advantage in the production and export of those branches where prices are lower than prices in the conditions of free trade. The term competitiveness, on the other hand, is understood more broadly, despite the factors affecting comparative advantages, including the influence of other factors, such as government policy (Branković, 2009). However, the identification of export competitiveness and comparative advantages of the national economy is not unfounded. It is based on the necessity that in analysing comparative advantages, neglecting strict, and often unrealistic, theoretical 
assumptions and to perform analysis based on real market situation and the available data.

First who stressed the importance of determining the sectors with the greatest export potential, based on the analysis of current export flows, was Liesner in 1958. Although this idea has been elaborated by many authors, the work of Bela Balassa (Balassa, 1965) contributes to its popularisation. Noting the difficulties in applying the concept of the traditional theory of comparative advantages in empirical analyses, Balassa, unlike classical trade theory which seeks to answer the question of what are the sources of comparative advantages, in the detection of the comparative advantages model focuses on their results. To this end, it is based on data of foreign exchange constructed an index that reveals the products in which the observed country has comparative advantages. Today, the Balassa index is one of the most commonly used instruments for analysis of comparative advantages of a national economy in international trade. Since such an analysis reveals the sectors in which one economy achieves the greatest comparative advantage, this index is known as the index of revealed comparative advantage or the RCA index (Revealed Comparative Advantage Index).

From the aspect of the present distance, it could be seen that the Serbian economy is significantly shifted on the development trajectory after the intensive implementation of the transition process. However, it takes a lot of effort to improve its development performance, in particular by the realisation of activities in order to improve its competitive position in the world market. The reason of that is that the competitiveness of an economy in modern conditions becomes a real framework for the development, and according to the latest Global Competitiveness Report, an unsatisfactory level of competitiveness of the Serbian economy is becoming a significant barrier to its further growth and development.

The economy of the Republic of Serbia disposes of significant natural and physical resources, thus the concept of factor intensity rank Serbia among the countries that are specialised in the production of products that to a greater extent rely on the use of natural inputs (physical labour and natural resources), and to a lesser extent in the production inputs (human resources and technology). Since 2000 the structure of merchandise exports of the Republic of Serbia has not significantly changed, because natural resources continue to hold primacy in the structure of merchandise exports (around one third of total merchandise exports), which is one of the reasons for its unsatisfactory competitive performance. From the aspect of the technological intensity of products, structure of merchandise exports shows that there has been some improvement competitiveness of the Serbian economy since in the period after 2000 there was an increase in participation of technologically intensive products to over 50\% (especially a group of medium-technology products), and decrease in the share of labour-intensive products in Serbian export (Bošnjak, 2005). A high percentage of natural resources 
and raw materials, labour-intensive products and low-intensive products in the structure of merchandise exports is unfavourable indicator of the product mix of the Serbian economy, but also the long-term unsustainability of comparative advantages, both in terms of exports and in terms of growth and development of the Serbian economy.

In accordance with the laid objective, this paper is structured as follows. After introductory considerations, the first part of the paper presented a brief review on the empirical literature on the issue of using the Balassa index in determining the comparative advantages in exports. In the second part of the paper, methodology and information base of research is exhibited and defined in the initial hypothesis. Research results and their discussion are presented in the third part of the paper. In order to strengthen the comparative advantages of the Republic of Serbia in the exchange of agricultural food products with the countries of the Western Balkans in the concluding remarks were given recommendations for desirable activities of competent authorities in this domain.

\section{Review of literature}

Theory of international trade, which is based on emphasising the importance of trade flows, gives the great priority to the concept of a competitive advantage. The basis of this theory is the specialisation of the agricultural production, where developed countries import from less developed countries, so the efficient use of resources and the availability of resources is important for the less developed economies.

Defining competitiveness in addition to traditional is the subject of modern theories and considerations, both at the macro and micro level. The traditional approach to defining competitiveness is based on the micro level, where the level of competitiveness of the economic subject is determined on the basis of the relative costs and market share, at the same time starting from the assumption of the existence of perfect competition. Modern approach to defining competitiveness is based on a macro level, providing a comprehensive interpretation of competitiveness. Unlike the traditional approach, a modern approach to defining competitiveness assesses the market position of the economic subject/economy not only on the basis of the relative costs and market share, but also includes innovations and modern technologies that have great significance for the market positioning.

Competitiveness is the ability of companies, industries, regions, nations or supranational regions to generate, while being and remaining exposed to international competition, relatively high factor income and factor employment levels on a sustainable basis (Balkytė \& Tvaronavičienè, 2010, p. 343). The ability to manufacture competitive products is mainly linked to individual firms and their 
ability to produce a competitive product. At the sector level, the competitiveness of the sector's ability to produce and export the number of different products compared to the competition. This concept includes several components that define the export competitiveness of a sector. First of all, to one sector or national economy to be competitive in the international market, it is necessary to first meet the needs and demands of the domestic market, then after settling domestic demand, with its competitive products conquer the foreign markets.

The components that determine competitiveness are the size and quality of export. Export size implies a penetration to foreign markets and the continuing expansion of the same. Determinants of the size of the export are volume and dynamics of export. The volume of export is by definition considered to be quantities of exported products (Balassa, 1967). He points to the acquired position of one export sector, as well as its strength in terms of capacity, resources and efficiency for the production of products that are exported. In this regard, the volume of export to some extent is a measure of a comparative advantage of one sector. By the concept of a competitive advantage is determined that the sector has the potential for further growth, while the comparative advantage describes export performance. From the theoretical point of view, continuously enhancing competitive advantage, will eventually lead to the improvement of comparative advantages.

For the purpose of measuring the importance of individual sectors of a country in the literature are used multiple techniques. Among the most commonly used methods in several empirical studies during the last three decades is the concept of Revealed Comparative Advantage (Revealed Competitive Advantage - RCA) developed by Balassa. In the next part of the paper we will take brief review of some of them.

Thus, for example, Yeats (1997) in his study employs a new methodological approach that measures production efficiency in changing trade patterns. Yeats used the RCA index in connection with the changes in the regional orientation of exports in order to identify any possible distortions in trade patterns for the Mercosur group of countries. It found that the most rapidly growing products in Mercosur's intratrade generally are goods in which members do not have a comparative advantage and have not been able to export competitively to outside markets. The results of his study showed that the Mercosur's discriminatory tariffs against nonmembers (which are four to six times higher than those in arrangements such as the European Union, European Free Trade Area, or North American Free Trade Agreement) are likely the cause of such distortion in trade patterns. It can be concluded that recent further increases in Mercosur's tariffs against nonmembers are likely to exacerbate the magnitude of trade diversion.

Richardson and Zhang (1999) compared US export performance between 1980 and 1995 using Balassa's export-based index of Revealed Comparative Advantage 
with 38 of its large trading partners, aggregating them into six regional groups, except China and Japan that are treated separately. They found temporally stable and ubiquitous US comparative advantage in differentiated producer goods (except disadvantage in Japan); somewhat less stable and less sweeping US disadvantage in standardised producer goods; and chaotic and diverse patterns of US RCA in consumer goods (especially in the Chinese market). The most significant findings of their study are sharp geographical differences in patterns of US RCA and small differences across sub-sectors of 1, 2, and 3-digit SITC classifications - regional, but not sectoral, niche specialization. According to these authors, the high overall variability across regions in RCA indexes seems unrelated to obvious explain actions such as proximity or lingual/historical ties to the US. In producer goods, RCA variability across regions correlates somewhat better with accounts of trade diversion and of regional preferences for and discrimination against US exports. The results of their study provided only scant evidence of high or increasing variability across disaggregated commodity sub-groups in US RCA indexes.

Bender and Li (2002) also applied the RCA concept in order to examine the export pattern related changes between Asian and Latin American economies over the period 1981-1997. They found that despite the fact that the RCA is not a perfect measure, it failed to distinguish between a region's factor endowment and changes in trade policy, it is still acceptable as the impact of changes in trade policies can be seen from movement of RCA. In other words, it provides indication on the movement in a region's comparative advantage. The results of their study indicate that East Asian economies are losing their comparative advantage to the lower-tier economies in Southeast Asia and Latin America, which confirms the hypothesis that changes in the export pattern are associated with shifts in comparative advantage among regions.

Ferto and Hubbard (2003) used the Balassa RCA index to examine competitiveness of Hungarian agricultural and food products in relation to the EU for a period from 1992-1998. They found that Hungary has a comparative advantage in a range of agri-food products, including animals and meat, which complements the findings of those studies that have used price and cost based approaches in identifying competitiveness in cereals and crops. Also, they emphasize that the RCA index, when interpreted as a binary measure, has remained stable during the period of transition, although there is evidence of a weakening in the level of comparative advantage as revealed in the Balassa index.

Hanif and Jafri (2006) examined the role of access to external finance on the textile export competitiveness of Pakistan by using the RCA index. They found that greater access to external finance resources has a positive impact in the improvement of country's textile sector competitiveness.

Burrange and Chaddha (2008) made an attempt to assess India's revealed comparative advantage in merchandise trade in a 10 years period (from 1996 to 
2005). They find that India enjoys comparative advantage in the exports of laborintensive items like textiles and scale-intensive items such as chemicals and iron and steel. Also, they attempt to evaluate India's RCA in exports and imports in different type of goods categorized on the basis of their production, grouped into Ricardo, Heckscher-Ohlin (HO), Product-cycle (PC) goods and Others. The obtained results suggest that India enjoys a comparative advantage in the exports of Ricardo and HO goods, while PC goods in contrast have not displayed any improvement in the RCA universe. On the import side, India enjoys a comparative advantage in the domain of Ricardo goods. They concluded that all production requiring standard technology is shifting to developing economies like India as reflected in the absence of RCA in imports of $\mathrm{HO}$ goods.

Comparative advantages in exports of agricultural and food products of Serbia into the European market has been the subject of the recent research of Ignjatijević, Babović and Đorđević (2012) In addition to the comparative method, the authors applied the Balassa Index of the revealed comparative advantage (RCA - Revealed Comparative Advantage) and a modified model of revealed comparative advantage $(\mathrm{Sm})$ in their study. By analysis the foreign trade in agricultural and food products they found that the products of outstanding comparative advantage are: cattle, corn, crude soybean oil, refined sugar and wheat flour; the products of significant comparative advantage are: raspberries, sugar-free mineral and carbonated water, sour cherries, refined sunflower oil, milk and sour cream, and mineral and carbonated water with added sugar; the products of satisfactory comparative advantage are: malt beer, corn seed and hybrid corn, non-alcoholic beverages (soft drinks), sweet biscuits, raw sunflower oil and food products made from cocoa. Also, they concluded that improving the competitiveness of agriculture and food industry depends on increasing yields, improving the organization and internal economy, the development of organic production and supply of high-quality certified range of final products in accordance with the demand in the world market.

Given the relatively sparse empirical studies of a comparative advantage in the export of agricultural and food products in the Western Balkans, this paper is inspired by the desire to contribute to filling this gap and its further development. The authors will apply the concept of Revealed Comparative Advantages with the aim to contribute to clearer understanding of the comparative advantages of the Republic of Serbia in the exchange of agricultural and food products with the other Western Balkans countries. Determining performance and quantification of one sector (in this case, agriculture) will provide data on how the country's exports reflects the competitive advantage or weakness in foreign markets (in this case the countries of the Western Balkans). 


\section{Research methodology, information base and research questions}

Agricultural-food products represent a very important segment in the foreign trade of the Republic of Serbia. Their presence is especially pronounced in exports, and is approximately around $20 \%$. On the import side, agricultural-food products are less common, and their share in total imports is below 10\% (Republika Srbija, Republički zavod za statistiku).

An export of agricultural-food products from the Republic of Serbia is predominantly focused on several groups of products, which occupy about $2 / 3$ of the total export of the Republic of Serbia. The most important products are of plant origin, as fruits, vegetables, and cereals and cereal products, followed by sugar and sugar products. Low representation of animal origin products in the total export indicates a high level of extensiveness of agriculture of the Republic of Serbia, concerning the unfavourable production structure in terms of the low representation of animal husbandry in the total agricultural production. In relation to the available agricultural resources, the Republic of Serbia has a relatively undeveloped livestock production, but also for years allowed for export shipment of beef to the EU of about 10,000 tons per year, is used marginally. On the other hand, for exports of pork and poultry meat in the EU the limitations are difficulties in meeting the rigorous standards set by the EU (Marković \& Zekić, 2006, p. 187).

Following the reaffirmation of the transition process in 2001, the value of merchandise exports of the Republic of Serbia has increased from year to year (with the exception of 2009, when under the influence of the global financial crisis was a nominal fall of the dollar value of exports to $1 / 4$, but the exception is 2012, when the recorded a nominal decrease of 5\%). It may be noted that until the start of the global economic crisis of 2008, the growth in imports was stronger, so that the foreign trade deficit also grew, and constantly was more than the value of merchandise exports. Since 2009, the growth rate of imports has been lower than the growth rate of exports, causing the value of the foreign trade deficit to decrease and stabilise (Milovanović, 2003, p. 121). This positive trend is the result of the recomposition structure of foreign trade exchange, and the result is to overcome the crisis in the Republic of Serbia.

Food production, food security, production of raw materials for other industries, trade with the world, social, demographic and other aspects determine the multiple significance of agriculture in the overall economic development of the Republic of Serbia. The importance of agriculture to the national economy confirmed its participation in the creation of GDP, which in recent years varies between $12-16 \%$, but if it takes into account overall contribution of agriculture to the other sectors of economy, this share exceeds $40 \%$ of GDP. The main problems facing the agriculture of the Republic of Serbia are the consequence of the 
limitations of central planning, decade-long delay in the implementation of the transition process and difficulties in adapting to a market economy.

In the context of an increasingly competitive international environment research of issues of the Serbian economy' comparative advantages gained in importance. For policy makers a good starting basis for taking the necessary actions towards improving the export competitiveness of the national economy is a comparison of the domestic economy with other economies. Just understanding the comparative advantages of the Republic of Serbia in foreign trade with the countries of the Western Balkans is the topic of this paper. Bearing in mind the aim and object of research, it can be carried out following research questions:

1. The exchange of agricultural-food products has a significant role in foreign trade of the Republic of Serbia and the Western Balkans.

2. The Republic of Serbia has a more pronounced competitive advantage in the exchange of agricultural-food products with the selected Western Balkans countries.

3. Extensibility of agriculture of the Republic of Serbia is an obstacle to the growth of competitiveness not only of agriculture but also the entire economy.

4. Government policy affects the competitive position of the country.

Analysis in this paper is based on the international classification, more accurate, the analysis includes the class of 29 (comprising mainly food products of animal origin, as well as vegetables and other horticulture products which have been prepared for use or preservation), class 30 (includes vegetable food products that have been prepared for use or preservation, as well as additives to improve the taste of food) and range 31 (which includes mainly fruits of the earth which have not been subject to any kind of preparation for consumption, live animals, as well as food for animals).

The following methods are used in the affirmation of the laid hypotheses: method of a comparative advantage, which indicates the current position of the Republic of Serbia in relation to the countries in the region in terms of foreign trade, historical method, taking into account the facts that follows the chronology of relations between Serbia and the countries in the region, trends method, which monitors future events, such as the Republic of Serbia's accession to the EU and the impact on the position of the Republic of Serbia in the world market, and last but not least important methods, standard methods, methods of analysis and synthesis of the research results. The application of comparative advantages method is based on the quantification of the Balassa index for agricultural products which are classified by the International Classification of Goods and Services. Information base of research represents data of the Chamber of Commerce of Serbia, Chamber of foreign trade of Bosnia and Herzegovina, monthly statistical 
bulletins and yearbooks of external trade statistics of the Republic Institute for Statistics of the Republic of Serbia, the statistics data of Belgrade Chamber of Commerce, and Development agency of Serbia. All collected and used data cover the time period from 2010 to 2015.

\section{Research results and their discussion}

Since the beginning of the transition process to date, the Republic of Serbia has achieved a significant increase in trade exchange with the world. From a regional perspective, it is most visible with the EU and the Western Balkan countries in transition. Foreign trade trends of the Republic of Serbia are to a great extent influenced by developments in domestic production and demand in the domestic market, but not by applied repertoire of economic policy measures and systemic economic change.

In the Republic of Serbia, there is no defined export strategy and production aimed at satisfying the sophisticated needs of the world market. In the structure of domestic exports dominates primary products and finished products of lower finalisation. In contrast, on the import side the primacy have consumer goods and materials for reproduction.

Trends and results in foreign trade in the previous transition period are of particular importance to economic development. Today, foreign trade must be seen as a strong growth factor stimulating competitiveness, not only as a factor in the supply of the domestic market and possibly the factor of domestic economic stability.

To the extent that competitiveness is a complex, evolving and rather vague concept, blurred with the subjective tendency of researchers to emphasise the importance of those economic phenomenon that have devoted their working life, complex, variable and incompletely defined become research method of the competitive position of the economy. Basic economic instruments for determining the competitive position of an entity in the international market based on an analysis of competitiveness indicators. The indicators are precisely defined economic relations whose values indicate the level of observed phenomena, in this case competition.

The method of the revealed comparative advantage (RCA - Revealed Comparative Advantages) that will be used in this analysis does not indulge in explanation of the reasons that lead to the comparative advantages of a country in international trade. On the basis of data on export performance, it detects whether there are comparative advantages, and by using different periods determines whether change in the structure of exports has been detected and whether there has been a change in the comparative advantages. 
The formula for calculating comparative advantage (RCA) was developed by Bella Ballasa, who introduced the so-called "Balassa index" in 1965 (Balassa, 1965). This index, in later years, was adjusted and modified and today represents the most commonly used method for measuring the comparative advantages of economies of individual countries in the international exchange of goods. Balassa RCA formula reads (Szymanik, 2012, p. 538):

$$
\mathrm{RCA}=\ln [\mathrm{Xi} / \mathrm{Mi}] \mathrm{x}[\Sigma \mathrm{Xi} / \Sigma \mathrm{Mi}] \text {. }
$$

Where

RCA - is revealed comparative advantage in year $t$,

$\mathrm{X} i$ - is export of product $i$ of the country $j$ in the year $t$,

$\mathrm{Mi}$ - is import of product $i$ of the country $j$ in the year $t$,

$\Sigma \mathrm{Xi}$ - is the total export of all products of the country $j$ in the year $t$,

$\Sigma \mathrm{Mi}$ - is the total import of all products of the country $j$ in the year $t$.

In this form $\mathrm{X}$ represents the value of export, and $\mathrm{M}$ is the value of import. The index $i$ represents a particular type of product. Positive values RCA index show that the economy has comparative advantages in the trade of the observed products. The higher the value of RCA index, the higher the comparative advantages of the economy. The minus sign RCA index shows the lack of comparative advantages.

In fact, this indicator is based on the current characteristics of the export, not the availability of factors of production in order to make up some theories. Value of the indicator of comparative advantage is computationally obtained, so that the ratio of export and import of goods between the two countries divided by a factor of total exports and imports of these countries (Balassa, 1967, p. 127).

The RCA index between the Republic of Serbia and Croatia shows that the comparative advantages of the Serbian economy are lower than its neighbours, i.e. Croatia has pronounced comparative advantages in the primary products with a relatively large share of labour-intensive production and low added value. From the calculated data it can be concluded that there is a modest export value of the Republic of Serbia into Croatia. The negative impact on the comparative advantages of the Republic of Serbia has the unfavourable exports structure from the structure of its imports.

Analysing the data in Table 1 it can be concluded that after the Croatian accession to the EU in 2013, the abolition of customs barriers, it came to an increase in both exports of the Republic of Serbia in this market, as well as imports, which provides a great opportunity for our placement of Serbian products, the expansion of the marketplace and strengthening comparative advantages. 
Table 1 Trade between the Republic of Serbia and Republic Croatia 2010-2015, in millions USD

\begin{tabular}{|c|c|c|c|c|c|}
\hline Year & $\begin{array}{c}\text { Total export } \\
\mathbf{( 1 )}\end{array}$ & $\begin{array}{c}\text { Total } \\
\text { import (2) }\end{array}$ & $\begin{array}{c}\text { Export } \\
\text { agric. } \\
\text { product. (3) }\end{array}$ & $\begin{array}{c}\text { Import } \\
\text { agric. } \\
\text { product. (4) }\end{array}$ & $\begin{array}{c}\text { RCA }^{\mathbf{a}} \\
(\mathbf{1} / \mathbf{2} \text { *(3/4) }\end{array}$ \\
\hline 2010 & 307,1 & 429,5 & 48,2 & 89,2 & 0,31 \\
\hline 2011 & 466,4 & 467,2 & 67,1 & 98,5 & 0,65 \\
\hline 2012 & 402,5 & 513,2 & 84,5 & 123,0 & 0,74 \\
\hline 2013 & 423,7 & 436,1 & 89,8 & 129,3 & 0,61 \\
\hline 2014 & 458,8 & 546,4 & 90,5 & 141,5 & 0,53 \\
\hline 2015 & 443,1 & 516 & 92,1 & 145,6 & 0,54 \\
\hline
\end{tabular}

${ }^{\text {a }}$ Authors' own calculations

Source: Privredna komora Srbije, Retrieved from:

http://www.pks.rs/Predstavnistva.aspx?id=9\&t=4\&jid=1, Accessed on 10 September 2016.

In order to increase the share of final products in the export of the Republic of Serbia to the EU market (which includes the Croatia), it is necessary to activate the economic policies measures that support exports. Although it is often emphasised that subsidising exports are prohibited by the rules of the World Trade Organization (WTO), there are other forgotten instruments. These are primarily the government's support to scientific research, promotion of the economy in abroad, regional development, which would be included in the export strategy, etc. Besides strengthening the financial potential of institutions that provide support to the export-oriented production development and export financing, as well as the implementation of other measures that indirectly operate on strengthening the export competitiveness of the economy, the export performance of the Serbian economy should improve and provide a sustainable increase in exports to the EU in the coming years.

In the export structure between the Republic of Serbia and Croatia predominate agricultural food products with low final processing, primarily raw materials. This structure is not satisfactory, it indicates a problem of Serbian refining complex, which to a country like Croatia can hardly compete (Vlahović et al, 2011). Regarding the structure of exports, from the Republic of Serbia to Croatia the most important export products are oil cakes, paper, cardboard, oil sunflower cake, sunflower oil, parts for engines, containers made of aluminum, corn, electricity, oil, soy, balloons, bottles etc. The most important goods imported from Croatia to the Republic of Serbia are urea, transformers, fertilizers, soya beans, cement, sunflower seeds, medicines, liquid petroleum gas, etc. Because of lower comparative advantages, the Republic of Serbia is bigger importer than exporter in the Croatian market. 
The relationship between the Republic of Serbia and the Republic of Croatia has been historically proved to be a key to the development of the Western Balkans region. Bilateral economic relations between the Republic of Serbia and the Republic of Croatia are regulated by the Agreement on Trade Cooperation, signed in 1998 between the Federal Government of the Federal Republic of Yugoslavia and the Government of the Republic of Croatia. After $1^{\text {st }}$ July 2013, i.e. Croatian accession to full membership in the EU, these relationships are governed by The Agreement on Economic Cooperation, signed in 2009, between the Government of the Republic of Serbia and the Croatian Government. In this way continuity of regulating economic cooperation and conditions for its further improvement are ensured. Croatia's entry into the EU is an incentive for the Republic of Serbia to modernise its products and production, in order to be able to export in the Croatian territory and in a wider area of the EU.

The RCA index of the Republic of Serbia and Bosnia and Herzegovina (Table 2) shows that the comparative advantages of the Serbian economy are higher compared to Bosnia and Herzegovina, i.e. that the Republic of Serbia has a pronounced comparative advantages. Within the region, the Republic of Serbia mostly trades with Bosnia and Herzegovina, particularly in the exchange of agricultural products, which has the largest surplus. Low participation of industry in the exchange of the Republic of Serbia and Bosnia and Herzegovina is a consequence of technical and technological underdevelopment of both countries.

The Republic of Serbia and Bosnia and Herzegovina are among the countries with a very high share of raw materials, while simultaneously with a very low proportion of high-tech products in total export, which indicates an unfavourable export structure. In the foreign trade of the Republic of Serbia with Bosnia and Herzegovina the number of products being imported is considerably smaller than the number of export products. A great impact on the low comparative advantage of Bosnia and Herzegovina has a lack of strategic products, low level of specialisation in production and indented exports.

Table 2 Trade between the Republic of Serbia and Bosnia and Herzegovina 2010-2015, in millions USD

\begin{tabular}{|c|c|c|c|c|c|}
\hline Year & $\begin{array}{c}\text { Total export } \\
\text { (1) }\end{array}$ & $\begin{array}{c}\text { Total } \\
\text { import (2) }\end{array}$ & $\begin{array}{c}\text { Export } \\
\text { agric. } \\
\text { product. (3) }\end{array}$ & $\begin{array}{c}\text { Import } \\
\text { agric. } \\
\text { product. (4) }\end{array}$ & $\begin{array}{c}\mathbf{R C A}^{\mathbf{a}} \\
\left(\mathbf{1} / \mathbf{2} \mathbf{*}^{*} \mathbf{( 3 / 4 )}\right.\end{array}$ \\
\hline 2010 & 281,5 & 159,4 & 184,5 & 72,3 & 2,50 \\
\hline 2011 & 229,2 & 179,2 & 144,1 & 75 & 2,46 \\
\hline 2012 & 292,6 & 128,9 & 148,2 & 66,2 & 5,12 \\
\hline 2013 & 249,8 & 140,4 & 137,7 & 70,5 & 3,48 \\
\hline 2014 & 346 & 146,5 & 198,1 & 72,2 & 6,47 \\
\hline
\end{tabular}




\begin{tabular}{|l|l|l|l|l|l|}
\hline 2015 & 367,9 & 140,7 & 201,5 & 69,7 & 7,55 \\
\hline
\end{tabular}

a Authors' own calculations

Source: Spoljnotrgovinska komora Bosne i Hercegovine, Retrieved from: http://komorabih.ba/vanjskotrgovinska-razmjena, Accessed on 15 September 2016.

Table 3 Trade between the Republic of Serbia and the Republic of Macedonia 2010-2015, in millions USD

\begin{tabular}{|c|c|c|c|c|c|}
\hline Year & $\begin{array}{c}\text { Total export } \\
\text { (1) }\end{array}$ & $\begin{array}{c}\text { Total } \\
\text { import (2) }\end{array}$ & $\begin{array}{c}\text { Export } \\
\text { agric. } \\
\text { product. (3) }\end{array}$ & $\begin{array}{c}\text { Import } \\
\text { agric. } \\
\text { product. (4) }\end{array}$ & $\begin{array}{c}\mathbf{R C A}^{\mathbf{a}} \\
\mathbf{( 1 / 2 ) * ( 3 / 4 )}\end{array}$ \\
\hline 2010 & 478,7 & 269,8 & 205,7 & 127,6 & 2,85 \\
\hline 2011 & 531,1 & 322,8 & 244 & 157,1 & 2,54 \\
\hline 2012 & 490,9 & 298,8 & 232,7 & 141,3 & 2,70 \\
\hline 2013 & 581,7 & 261,6 & 278,9 & 139,3 & 4,44 \\
\hline 2014 & 603,7 & 252,3 & 297,7 & 137,7 & 5,16 \\
\hline 2015 & 522,5 & 203,5 & 241,7 & 130,1 & 4,75 \\
\hline
\end{tabular}

${ }^{\text {a }}$ Authors' own calculations

Source: Privredna komora Beograda, Retrieved from:

http://www.kombeg.org.rs/Komora/udruzenja/UdruzenjeTrgovine.aspx?veza=1404 Accessed on 15 September 2016.

By signing the CEFTA agreement, the Republic of Serbia's foreign trade has been liberalised with all countries signatories of the agreement, including the Republic of Macedonia. The calculated RCA indicator for the period (Table 3), shows greater competitiveness of the Republic of Serbia in relation to Macedonia, but also very important foreign trade with a tendency of growth. The most important products exported by the Republic of Serbia into the Republic of Macedonia are cereals, cereal products, milk and eggs, while in imports are dominated by fruit, vegetables, tobacco, meat and meat products (Adapted from: Tomić \& Vlahović, 2003, 189).

Table 4 Trade between the Republic of Serbia and Albania 2010-2015, in millions USD

\begin{tabular}{|c|c|c|c|c|c|}
\hline Year & $\begin{array}{c}\text { Total export } \\
\text { (1) }\end{array}$ & $\begin{array}{c}\text { Total } \\
\text { import (2) }\end{array}$ & $\begin{array}{c}\text { Export } \\
\text { agric. } \\
\text { product. (3) }\end{array}$ & $\begin{array}{c}\text { Import } \\
\text { agric. } \\
\text { product. (4) }\end{array}$ & $\begin{array}{c}\mathbf{R C A}^{\mathbf{a}} \\
(\mathbf{1 / 2})^{\mathbf{*}(3 / 4)}\end{array}$ \\
\hline 2010 & 131,01 & 8,1 & 72,3 & 5,5 & 21,25 \\
\hline 2011 & 127,1 & 22,6 & 69,1 & 17,1 & 22,71 \\
\hline 2012 & 87,6 & 13,9 & 56,1 & 9,8 & 36,06 \\
\hline
\end{tabular}




\begin{tabular}{|c|c|c|c|c|c|}
\hline 2013 & 120,1 & 16,6 & 70,5 & 12,5 & 40,78 \\
\hline 2014 & 97 & 11 & 60,4 & 8,3 & 64,18 \\
\hline 2015 & 64,3 & 12,5 & 44,4 & 9,7 & 23,53 \\
\hline
\end{tabular}

a Authors' own calculations

Source: Privredna komora Beograda, Retrieved from:

http://www.kombeg.org.rs/Komora/udruzenja/UdruzenjeTrgovine.aspx?veza=1404\#cefta, Accessed on 15 September 2016;

INSTAT (2016) External trade in goods by enterprises characteristics 2012 - 2015, Retrieved from: http://www.instat.gov.al/media/334321/tregtia_jashtme_sipas_ karakteriatikave_te_ndermarrjeve_2015.pdf, Accessed on 15 September 2016.

In comparison to other analysed countries, the RCA indicator in the case of the Republic of Serbia and Albania (Table 4) shows a very high competitiveness of the Republic of Serbia in regard to the Republic of Albania. Trade relations are not balanced, as Albanian companies are not sufficiently present in the Serbian market. In order for trade relations to become stable and advanced, trade benefits to investors are required in order that investors and business people of both countries have the same position. Balanced trade would contribute to better cooperation. The Government of the Republic of Serbia and the Republic of Albania should be aware that domestic production in both countries, if not increased, and if there are not efforts to prepare it for competition in the EU market, will suffer losses.

The products exported by the Republic of Serbia to the Republic of Albania are mainly agricultural products, yellow corn, wheat flour, sunflower oil, common wheat, bakery products and the like. As for imports, there are generally represented irons, bitumen, profiles of aluminum alloys, footwear, clothing, etc.

In the case of the Republic of Serbia and Montenegro (Table 5), the RCA indicator shows the reported competitive advantage of the Serbia economy. In the Serbian structure of import from Montenegro the most common are: wine, beer, lignite, iron, steel, and as far as exports are: milk, natural and carbonated water, various kinds of flour, etc. (Privredna komora Srbije).

Table 5 Trade between the Republic of Serbia and Montenegro 2010-2015, in millions USD

\begin{tabular}{|c|c|c|c|c|c|}
\hline Year & $\begin{array}{c}\text { Total export } \\
\mathbf{( 1 )}\end{array}$ & $\begin{array}{c}\text { Total } \\
\text { import (2) }\end{array}$ & $\begin{array}{c}\text { Export } \\
\text { agric. } \\
\text { product. (3) }\end{array}$ & $\begin{array}{c}\text { Import } \\
\text { agric. } \\
\text { product. (4) }\end{array}$ & $\begin{array}{c}\text { RCA }^{\mathbf{a}} \\
(\mathbf{1} / \mathbf{2} \text { *(3/4) }\end{array}$ \\
\hline 2010 & 809,9 & 151,8 & 457,4 & 65,2 & 37,39 \\
\hline 2011 & 901,5 & 112,5 & 469,1 & 50,1 & 75 \\
\hline 2012 & 814,7 & 108,3 & 462,4 & 52 & 66,87 \\
\hline 2013 & 862,0 & 160,9 & 437,7 & 68,9 & 34 \\
\hline
\end{tabular}




\begin{tabular}{|l|c|c|c|c|c|}
\hline 2014 & 486,93 & 74 & 370,2 & 42,1 & 57,77 \\
\hline 2015 & 670,91 & 160 & 490,7 & 50,1 & 41,04 \\
\hline
\end{tabular}

a Authors' own calculations

Source: Privredna komora Beograda, Retrieved from: http://www.kombeg.org.rs/Komora/udruzenja/UdruzenjeTrgovine.aspx?veza=1404\#cefta, Accessed on 15 September 2016; Razvojna Agencija Srbije, Retrieved from:

http://ras.gov.rs/sr/podrska-izvozu/izvoz-u-brojkama, Accessed on 15 September 2016.

Despite the tendency of growth of exports of the Republic of Serbia, there are numerous problems faced by exporters. First of all, the high interest rates are presented in the domestic market so that enterprises borrow only out of necessity. Foreign banks prefer lending to domestic consumption. The lack of working capital to finance production is accompanied by a shortage of funds for financing and insurance of export transactions. In order to eliminate this restriction, it is necessary to provide adequate financial potential of the Fund for Insurance and Export Credit, and to strengthen the country's engagement in the area of export promotion of the entire economy (Kovačević, 2006).

Domestic economy's lagging behind foreign economies of about several technology cycles cannot be a satisfactory basis for the growth of competitive exports. Therefore, we should not lose sight of the expressed interest of foreign customers for domestic companies, and only then for export.

Despite relatively low wages compared to developed countries and new EU Member States, production in the Republic of Serbia is characterised by slowness in introducing new products, due to insufficient innovative activity, and because of the relatively low level of foreign direct investment (Đorđević et al., 2006, p. 15). Still unfavourable investment climate can affect the growth of operating costs, which is poured out on the competitiveness of production in the Republic of Serbia, and act negatively on the formation of new export products.

\section{Conclusion}

The Western Balkan countries have experienced a significant transformation in the last 15 years, by the implementation of a comprehensive programme of economic and social reforms. However, despite the efforts, the Western Balkan countries are still far behind the European Union in terms of competitiveness, income levels and living standards.

The question of raising the competitiveness and enabling the national economy to successfully integrate into the EU market is a question of the development strategy that is based on real market exchange rate and the liberalisation of foreign trade. In this way, the investment is directed at creating a new, modern structure of the economy, competitive on domestic and foreign markets. Investments in modern 
equipment and production processes are the key preconditions for improving competitiveness and spurring exports. Increase of export revenues is the first condition of servicing foreign debt and providing financing for the import of equipment and technology, and that means a condition of economic development in the coming years.

To achieve economic growth and to achieve a constant increase in gross domestic product and the living standard, the Republic of Serbia must achieve global competitiveness, primarily in the markets of EU countries with which is held the largest part of foreign trade and capital flows. The competitiveness of the Republic of Serbia can be improved by increasing the rate of economic growth and increasing exports. In order to achieve this, it is necessary to focus on the comparative advantages.

The analysis of export competitiveness in this paper confirms that the exchange of agricultural-food products has a significant role in the foreign trade of the Republic of Serbia and the Western Balkans. Also it shows that the Republic of Serbia in the observed period recorded a positive competition, and that has made the greatest comparative advantage in agriculture and agribusiness. By applying the RCA indicator it was found that the Republic of Serbia has distinct comparative advantages in relation to selected countries in the region, with the exception of the Republic of Croatia. This gives the answer on the second research question laid in this paper.

The main factor of competitiveness in the Republic of Serbia at the moment is the low price of agricultural products caused as a result of low labour costs and low land prices (due to the lack of an active land market). However, these are factors that cannot be factors of competitiveness in the long term, even in the geographical environment which occupied the Republic of Serbia. The space for the growth of competitiveness lies in the significant natural resources that place the Republic of Serbia among the top European countries, in the sphere of improving quality standards, and improving the product programme, faster innovation penetration and more solid production chain.

The changes to be implemented in the agricultural policy are reflected in the reallocation of resources from direct support to the investment policy and support rural development. Also, there is a need for changes in the direction of orientation of the budget funds, from large agricultural entities (companies, cooperatives and agriculture companies), to the family commercial farms. The aim of these changes is to increase the competitiveness of agriculture in the Republic of Serbia (Jefferson Institute, 2003, p. 124).

The reform processes in international trade contribute to the removal of import barriers, the integration processes in the economy, the growth of productivity and income of farmers. Though, extensibility of the Republic of Serbia agriculture 
sector is an obstacle to the growth of competitiveness not only for the agriculture but also the entire economy, which was confirmed in the practice. The main directions of future development of the Serbian agriculture are an optimal utilization and conservation of available production capacity, increase in the volume of agricultural production, change in the production structure in favour of intensive agriculture for export, production of finished and high-quality products. The aim of such development directions is to satisfy domestic demand and a significant increase in exports of high-quality agricultural products.

Development of the agriculture of the Republic of Serbia is directed to modernization and changing of production structure towards greater market orientation and improve the overall efficiency of agriculture. Production and technological restructuring and productivity growth in agriculture, and greater competitiveness in domestic and international markets will be based on environmental, energy and economic criteria.

The development of scientific research and the application of existing and new knowledge and technology will enable significant increase in the volume of agricultural production and the economy of the Republic of Serbia. Faster changes in production structure, for objective reasons, cannot be implemented in the short term, but gradually, depending on the pace of recovery process of Serbian agriculture and primarily, its financial consolidation. Therefore, the gradual establishment of the required structures of production, the bigger production of industrial crop production and livestock intensification are recommended.

The lack of regulated agricultural information system of the Republic of Serbia FADN (Farm Accountancy Data Network) which would provide accurate data, that are important for the analysis of this issue, were imposed as a limitation in the study of this topic.

The main objective of the agricultural policy of the Republic of Serbia is to build a sustainable and efficient agricultural sector that can compete in the world market, contributing to the growth of national income. The agriculture of the Republic of Serbia is facing many problems that are primarily the result of low investment assets, which caused the relatively low competitiveness and lagging behind (Vlada Republike Srbije, 2014).

The issue of competitiveness is the subject of frequent analysis, particularly agriculture, since it represents an important, if not the largest source of the same for the economy of the Republic of Serbia. Significance of this point by the analysis of competitiveness using the Balassa index, requires a review of the problem from a different angle. Great importance for the analysis of this issue has the role of the state, whose agricultural policy measures may well affect the competitiveness of agriculture and contribute to overall competitiveness. In accordance with this, it 
can be concluded that an appropriate government policy affects the competitive position of the country.

The new conditions for agriculture of the Republic of Serbia has already been created and are reflected in the transition from a centrally planned economy, in which the greatest responsibility is on the state apparatus, to a market, where in the centre of responsibility is individual. The new integration processes (EU accession) will further change economic conditions, which will be reflected to a greater liberalisation of agriculture and therefore require even greater competitiveness.

As an emerging issue that arises from the analysis of the competitiveness of agricultural production, which can serve as recommendations for improving the competitiveness of agriculture of the Republic of Serbia is a question of agricultural policy reform and its impact on agriculture as an important factor for improving competitiveness on the path of European integration.

Since the production and economic potential that the Republic of Serbia possesses in the agricultural sector has not been used to the extent provided by the rich natural resources in the future, it is necessary to undertake a radical change in the direction of strengthening the competitiveness of agriculture, which should be aimed at: strengthening the technical and technological production base and optimal utilization of production capacity, changes of agricultural structure in the direction of enlarging farms, changing the production structure in favour of increasing the share of products higher technological level of processing for export, production of high quality finished products that settled on the world market in terms of standards and procedures related to food safety food, and especially the increase in the share of livestock in the value of agricultural production in accordance with the need of development of the food industry.

\section{References}

Balassa, B. (1965). Trade liberalization and revealed comparative advantage. The Manchester School of Economic and Social Studies, 33, 99-123.

Balassa, B. (1967). Trade liberalization among industrial countries. New York: McGrawHill Book Company.

Balkytè, A. \& Tvaronavičienè, M. (2010). Perception of competitiveness in the context of sustainable development: Facets of "sustainable competitiveness". Journal of Business Economics and Management, 11(2), 341-365.

Bender, S., Li, Kui-Wai (2002). The changing trade and revealed comparative advantages of Asian and Latin American manufacture exports, (Working Papers 843), Yale University: Economic Growth Center.

Bogdanov, N., Božić, D. \& Munćan, P. (2004). Ocena efekata integracije u WTO i EU na poljoprivredu Srbije. Ekonomika poljoprivrede, 51 (3-4), 249-256.

Bošnjak, M. (2005). Konkurentnost i razvoj kao poluge evropske perspektive Srbije. Ekonomski anali, 166, 129-148. 
Branković, A. (2009). Izvozna konkurentnost privrede Republike Srbije pod uticajem tranzicionih promena. Beograd: Institut ekonomskih nauka.

Burrange, L. G. \& Chaddha, S. J. (2008). India s' revealed comparative advantage in merchandise trade, (Working Paper UDE 28/6/2008), University of Mumbai: Department of Economics.

Buturac, G. (2009). Regionalne sličnosti i razlike strukture međunarodne trgovine u Hrvatskoj. Zbornik Ekonomskog fakulteta, 7(1), 1-16.

Đorđević, M., Stevanović S. \& Lazić. (2006). Domaće tržište i Srbija u spoljno-trgovinskoj razmeni. Zemun: DAES.

Ferto, I. \& Hubbard, L. J. (2003). Revealed comparative advantage and competitiveness in Hungarian agri-food sectors. The World Economy, 26 (2), 247-259.

Hanif, M. N. \& Jafri, S. K. (2006). Financial development and textile sector competitiveness: A case study of Pakistan. South Asia Economic Journal, 9 (1), 141158.

Ignjatijević, S., Babović, J., Đorđević, D. (2012), Balasa index u određivanju komparativnih prednosti poljoprivrednih proizvoda u izvozu. Teme, 36 (4), 17831800.

INSTAT (2016). External trade in goods by enterprises characteristics 2012 - 2015, Retrieved from: http://www.instat.gov.al/media/334321/tregtia_jashtme_sipas_ karakteriatikave_te_ndermarrjeve_2015.pdf, Accessed on 15 September 2016.

Jefferson Institute (2003). Konkurentnost privrede Srbije. Beograd: Jefferson Institute.

Kovačević, R. (2006). Mogućnosti i ograničenja porasta izvoza kao faktor platnog bilansa Srbije, Retrieved from: http://www.doiserbia.nb.rs/img/doi/0025-8555/2006/002585550604492K.pdf, Accessed on 15 August 2016.

Marković, K. \& Zekić, S. (2006). Liberalizacija trgovine kao uslov za integraciju Republike Srbije u međunarodne ekonomske tokove. Zemun: DAES.

Milovanović, M. (2003). Spoljno-trgovinska razmena poljoprivrednih proizvoda. Tržište hrane, Beograd.

Ministarstvo poljoprivrede, vodoprivrede i šumarstva, (2010). Efekti liberalizacije carina na liberalizaciju poljoprivrede Republike Srbije, Retrieved from: https:/www.agrarije.com/sites/default/files/Efekti\%20liberalizacije\%20na\%20poljo privredu\%20Srbije.pdf, Accessed on 15 August 2016.

Ministarstvo regionalnog razvoja i lokalne samouprave (2014). Sličnosti $i$ komplementarnosti privredne strukture Republike Srbije i Republike Srpske kao osnove jačanja ekonomske saradnje. Beograd.

Nešić, S. (2008). Konkurentnost privrede Srbije. Beograd: Srpski ekonomski forum.

Porter, M. (1990). The Competitive Advantages of Nations. London and Basingstoke: McMillan.

Privredna komora Beograda, Retrieved from: http://www.kombeg.org.rs/Komora/ udruzenja/UdruzenjeTrgovine.aspx?veza=1404, Accessed on 15 September 2016.

Privredna komora Srbije, Retrieved from: http://www.pks.rs/Predstavnistva.aspx? id=9\&t=4\&jid=1, Accessed on 10 September 2016.

Razvojna Agencija Srbije, Retrieved from: http://ras.gov.rs/sr/podrska-izvozu/izvoz-ubrojkama, Accessed on 15 September 2016.

Republički zavod za statistiku (2015). Ekonomski računi poljoprivrede u Republici Srbiji, 2007-2013. Beograd. 
Republika Srbija, Republički zavod za statistiku, Retrieved from: http://webrzs.stat.gov.rs/WebSite, Accessed on 15 August 2016.

Richardson, D. J. \& Zhang, C. (1999). Revealing comparative advantage: Chaotic or coherent patterns across time and sectors and U.S. trading partners? (NBER Working Paper, WP7212), Cambridge, MA: National Bureau of Economic Research.

Spoljnotrgovinska komora Bosne i Hercegovine, Retrieved from: http://komorabih.ba/vanjskotrgovinska-razmjena, Accessed on 15 September 2016.

Szymanik, E. (2012). The competitiveness of the export from poland to the baltic countries, Retrieved

from: http://leidykla.vgtu.lt/conferences/BM_2012/international_economy/537_543_Szym anik.pdf, Accessed on 15 September 2016.

Tomić, D. \& Gulan, B. (2008). Povećanje konkurentnosti u agrobiznis sektoru Srbije činilac poboljšanja spoljno-trgovinske razmene. Ekonomski anali, Beograd.

Tomić, D. \& Vlahović B. (2003). Proširenje Evropske unije i poljoprivreda Balkanskih zemalja. U: Poljoprivreda i ruralni razvoj u evropskim integracijama (pp. 235240). Zemun.

Vlada Republike Srbije (2014). Strategija poljoprivrede i ruralnog razvoja Republike Srbije za period od 2014-2024, Retrieved from: http://www.srbija.gov.rs/vesti/dokumenti_sekcija.php?id=45678, Accessed on 15 August 2016.

Vlahović, D., Tomić, D. \& Kuzman, B. (2011). Spoljnotrgovinska razmena agroindustrijskih proizvoda Republike Srbije i Hrvatske. Tranzicija, 27.

World Economic Forum (2008). The Global Competitiveness Report 2008-2009.

World Economic Forum (2008). The Global Competitiveness Report 2008-2009. Geneva: Switzerland.

Yeats, A. J. (1997). Does Mercosur's trade performance raise concerns about the effects of regional trade arrangements. The World Bank: International Economics Department.

\section{ANALIZA IZVOZNE KONKURENTNOSTI POLJOPRIVREDNIH PROIZVODA REPUBLIKE SRBIJE NA OSNOVU RCA INDEKSA}

Apstrakt: Poljoprivreda Republike Srbije je značajna ekonomska grana, kako zbog specifičnosti proizvodnje, tradicije, tako i zbog ogromnog potencijala koje ona poseduje za unapređenje konkurentskih performansi i razvoja nacionalne ekonomije. Upravo iz tog razloga, u svim strateškim dokumentima poljoprivreda je prepoznata kao vitalna grana za razvoj nacionalne ekonomije, što se može postići porastom produktivnosti i većom spoljnotrgovinskom razmenom, naročito sa zemljama u okruženju. Imajući u vidu da poljoprivredno prehrambeni proizvodi predstavljaju veoma značajan segment u spoljnotrgovinskoj razmeni Republike Srbije sa zemljama zapadnog Balkana, cilj istraživanja je da se primenom Balassa indeksa ukaže na komparativne prednosti Republike Srbije u razmeni poljoprivredno-prehrambenih proizvoda sa odabranim zemljama regiona. Ostvarivanje osnovnog cilja istraživanja izvršeno je primenom metoda komparativnih prednosti, istorijskog metoda, 
metoda trenda, metoda analize i sinteze. Dobijeni rezultati istraživanja pokazuju da Republika Srbija ima izražene komparativne prednosti u odnosu na odabrane zemlje zapadnog Balkana, izuzev Republike Hrvatske. Ključni doprinos ovog rada ogleda se u pružanju jasnijeg uvida u komparativne prednosti Republike Srbije u spoljnotrgovinskoj razmeni sa odabranim zemljama regiona, kao i ukazivanju u kom pravcu bi trebalo da se kreću prioritetne aktivnosti nadležnih državnih organa kako bi se intenzivirao izvoz poljoprivrednih, pre svega visoko kvalitetnih i proizvoda na višem stepenu obrade.

Ključne reči: komparativne prednosti, poljoprivreda, RCA indikator, Republika Srbija, zemlje zapadnog Balkana.

\section{Author's biographies}

Milica Cvetković graduated from the Faculty of Economics, University of Niš in October 2009, the module General Economy. In November 2010, at the same University, she completed a Master's degree in General Economics, defended the Master's thesis on the subject Competitiveness in the market of agricultural products. Currently, she is a $\mathrm{PhD}$ student at the Faculty of Economics in Niš. She is a scholar of the Ministry of Education, Science and Technological Development.

Marija Petrović-Ranđelović graduated from the Faculty of Economics in 2000. She received her MSc (2005) at the Faculty of Economics in Belgrade and $\mathrm{PhD}$ (2010) at the Faculty of Economics in Nis. She is an Associate Professor at the Faculty of Economics, University of Nis. She is the author of more than hundred scientific and professional papers. Her research interests refer to the problems in the domain of the national economy, economic policy, and economic development and especially foreign direct investment and economic development and growth. She has been participated in many project financed by the Ministry of Science of the Republic of Serbia. 